\title{
PENGARUH PENGUASAAN KOSA KATA TERHADAP KEMAMPUAN MENULIS BAHASA ARAB SISWA KELAS VIII MTS ASSALAM BANGILAN TUBAN TAHUN PELAJARAN 2019/2020
}

\author{
Ana Achoita \\ Institut Agama Islam Nahdlatul Ulama Tuban \\ Email: anaachoita@stitmatuban.ac.id \\ Juwini Sri Susanti \\ Institut Agama Islam Nahdhotul Ulama Tuban \\ Email: Annafarizsanti@gmail.com
}

\begin{abstract}
Abstrak
Tujuan penelitian ini adalah mendiskripsikan pengaruh penguasaan kosa kata terhadap kemampuan menulis bahasa Arab siswa kelas VIII MTs Assalam Bangilan Tuban. Metode penelitian yang digunakan dalam penelitian ini adalah metode penelitian kuantitatif, sedangkan jenis penelitian yang digunakan yaitu penelitian percobaan (eksperimental research). Pada penelitian ini peneliti menggunakan pre-test dan post-test control grup disign (two grup design) untuk mengetahui pengaruh penguasaan kosa kata terhadap kemampuan menulis bahasa Arab. Hasil dari penelitian ini menunjukkan ratarata penguasaan kosa kata kelas eksperimen sebesar 65 yang artinya siswa cukup menguasai dengan baik kosa kata yang diberikan. Adapun rata-rata penguasaan kosa kata kelas kontrol sebesar 79 yang artinya kelas kontrol mengusai kosa kata dengan baik. Sedangkan rata-rata kemampuan menulis bahasa Arab kelas eksperimen sebesar 71 yang artinya siswa cukup mampu dalam menulis bahasa Arab dan rata-rata kemampuan menulis bahasa Arab kelas kontrol sebesar 76 yang artinya kelas kontrol mampu menulis bahasa Arab dengan baik. Hasil dari uji $\mathrm{T}$ pre and post test control grup design, diperoleh $\mathrm{t}$ hitung sebesar 2,313. Kemudian dibandingkan dengan $\mathrm{t}$ tabel sebesar 2,006 pada taraf signifkasi 5\%. Hasil perbandingan tersebut menunjukkan $t$ hitung $(2,313)>t$ tabel $(2,006)$, hal ini menunjukkan bahwa ada pengaruh antara penguasaan kosa kata terhadap keterampilan menulis bahasa Arab kelas VIII MTs Assalam Bangilan Tuban.
\end{abstract}

Kata Kunci: Penguasaan Kosa Kata, Menulis bahasa Arab.

\section{PENDAHULUAN}

Bahasa Arab merupakan bahasa asing yang bisa dipelajari dengan berbagai cara pengajaran inovatif dalam pengajarannya. Belajar bahasa Arab memerlukan usaha dan motivasi yang kuat, dan keberhasilan suatu pembelajaran tidak hanya mengenai ketepatan dan peran media pembelajarannya, akan tetapi juga bergantung pada usaha siswa dalam mengembangkan atau mengamalkan ilmu yang diterima.

Ghazawi (dalam Arsyad, 2010: 1) mengatakan bahwa bahasa Arab merupakan salah satu bahasa mayor didunia yang dituturkan oleh lebih dari 200.000.000 umat manusia. Bahasa Arab merupakan bahasa yang sangat penting karena bahasa Arab merupakan bahasa Al-Qurān yang mana Al-Qurān adalah kitab sucinya umat Islam.

Menurut Al Ghalayaini (dalam Achoita, 2018: 3) bahasa Arab dapat didefinisikan dengan: 


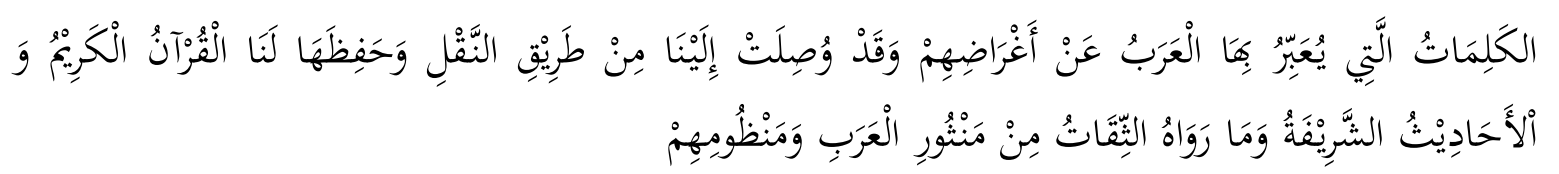

"Berbagai kata yang digunakan orang-orang Arab untuk mengungkapkan berbagai maksud atau tujuan mereka, disampaikan pada kita dengan jalan menukil/transfer/riwayat, dihimpun dan dijaga kepada kita oleh Al-Qurān yang mulia dan hadis hadis mulia dan berbagai riwayat terpercaya berupa prosa-prosa dan syair-syair Arab".

Kebutuhan masyarakat akan penguasaan bahasa Asing yang baru-baru ini berkembang, tidak hanya terbatas bahasa Inggris akan tetapi juga bahasa Arab. Hal ini terkadang memaksa sekolah untuk memanfaatkan guru agama Islam atau guru yang tidak berlatar belakang pendidikan bahasa Arab untuk mengajarkannya. Akibatnya kegiatan belajar mengajar hanya sebatas formalitas tidak lebih. Sehingga siswa tidak dapat mencapai target yang diharapkan, bahkan meskipun mereka telah mempelajarinya sekian tahun.

Kita semua menyadari, bahwa penguasaan bahasa Asing bagi negara kita merupakan faktor yang penting, karena dalam berbagai aspek bisa membantu kelancaran usaha pembangunan. Kita harus menyadari pula, bahwa hasil pengajaran bahasa Asing di berbagai lembaga pendidikan belum mencapai hasil yang diharapkan. Salah satu kelemahan pada umumnya terletak pada metode pengajaran yang belum menjurus pada penguasaan struktur-struktur dasar secara lisan, yang merupakan landasan untuk mengembangkan kemampuan pasif maupun aktif. Selain juga dampak dari pemanfaatan tenaga pengajar yang tidak kompeten di bidang tersebut.

Beberapa ahli linguistik dan psikologi berpendapat bahwa tidak perlu dan tidak mungkin mengadakan perbedaan antara language dan speech, karena keduanya mempunyai hubungan yang sangat erat (Hardjono, 1988: 35). Mengingat language (bahasa) adalah alat untuk berkomunikasi dan speech (berbicara) adalah proses berkomunikasi dengan menggunakan bahasa.

Bahasa adalah sistem lambang bunyi yang arbitrer yang dipergunakan oleh anggota kelompok sosial untuk bekerja sama, berkomunikasi dan mengidentifikasikan diri (Kentjono, 1990: 2). Dari sinilah muncul anggapan bahwa native speaker (penutur asli) yang merupakan anggota kelompok sosial dari bahasa yang bersangkutan mutlak dimiliki oleh kelas bahasa Asing. Sebenarnya mengajar bahasa Asing tidak harus menggunakan penutur asli (native speaker). Sebab penutur asli belum tentu memahami apa yang menjadi kesulitan para siswa Indonesia. 
Dalam pengajaran bahasa Arab khususnya untuk pemula penguasaan kosa kata harus dimiliki. Kosa kata memiliki peranan yang sangat penting dalam bahasa Arab, terutama dalam mengembangkan kemampuan berbahasa. Bagi pemula hendaknya menguasai kosa kata yang cukup untuk mengembangkan kemampuan berbahasa baik kemampuan berbicara atau kemampuan menulis. Menurut Rasyidi (2017: 63) "Kemampuan berbahasa secara konvesional memiliki empat jenis kemampuan, di antaranya kemampuan menyimak, kemampuan berbicara, kemampuan membaca dan kemampuan menulis".

Menurut effendy (2012: 105) "Performansi dan kemampuan berbahasa bermacam-macam. Ada yang berbentuk lisan dan ada juga yang berbentuk tulisan ada yang bersifat reseptif yaitu menyimak dan membaca dan ada yang bersifat produktif yaitu berbicara dan menulis".

Berbicara dan menulis merupakan dua dari empat keterampilan berbahasa. Tidak semua orang yang faham bahasa Arab mampu berbicara menggunakan bahasa Arab dengan baik. Seseorang mampu berbicara menggunakan bahasa Arab dengan baik jika mempunyai banyak kosa kata. Karena kosa kata merupakan salah satu hal yang sangat penting dalam berbahasa. Begitupun dengan menulis bahasa Arab, jika seseorang tidak memiliki kosa kata yang banyak dia tidak akan bisa menulis bahasa Arab. Semua orang bisa menulis bahasa Arab jika mempunyai banyak kosa kata akan tetapi hasil karyanya akan baik jika orang tersebut mengetahui tatacara/teknik penulisannya.

Effendy (dalam Mustofa, 2017: 69) menyampaikan bahwa tahapan dan teknik-teknik pembelajaran kosa kata atau pengalaman siswa dalam memperoleh makna kata dapat dijelaskan sebagai berikut :

a. Mendengarkan kata

Ini merupakan tahapan pertama yaitu dengan memberikan kesempatan kepada siswa untuk mendengarkan kata yang diucap pengajar atau media lain, baik berdiri sendiri maupun dalam kalimat. Apabila usur bunyi sudah dikuasai oleh siswa, maka untuk selanjutnya siswa akan mampu mendengarkan dengan benar.

b. Mengucapkan kata

Dalam tahap ini pengajar memberi kesempatan kepada siswa untuk mengucapkan kata yang telah didengarnya. Mengucapkan kata baru akan membatu siswa mengingat kata tersebut dalam waktu yang lebih lama.

c. Mendapatkan makna kata

Pada tahap ini hendaknya pengajar menghindari terjemahan dalam memberi arti kata kepada siswa, karena bila itu dilakukan maka tidak akan terjadi komunikasi langsung dalam bahasa yang telah dipelajari, sementara makna katapun akan cepat dilupakan oleh siswa. Ada 
beberapa teknik untuk menghindari hal ini diantaranya, definisi sederhana, pemakaian gambar/foto, antonim, sinonim, maupun memperlihatkan benda asli atau tiruanya. Jika kata memang sangat sulit untuk dicari bisa juga menggunakan peragaan gerakan tubuh.

d. Membaca kata

Setelah ketiga tahap diatas dilakukan, pengajar menulisnya dipapan tulis, kemudian memberi kesempatan siswa untuk membaca kata tersebut dengan suara keras.

e. Menulis kata

Penguasaan kosakata siswa akan sangat terbantu bilamana ia diminta untuk menulis katakata yang baru dipelajarinya.

f. Membuat kalimat

Tahap terakhir dalam kegiatan pembelajaran kosa kata adalah menggunakan kosa kata yang baru dalam sebuah kalimat yang sempurna, baik secara lisan maupun tulisan. Guru harus kreatif dalam memberikan contoh kalimat-kalimat yang bervariasi dan siswa diminta untuk menirukannya. Dalam menyusun kalimat-kalimat itu hendaknya digunakan kata-kata yang produktif dan aktual agar siswa dapat memahami dan mempergunakannya sendiri.

Secara umum bentuk kosa kata bahasa Arab dibagi menjadi dua diantaranya :

a. Kosa kata yang bisa mengalami perubahan yakni kosa kata yang diambil dari kata lain. Kosa kata yang mengalami perubahan bentuk tidak hanya berubah bentuk akan tetapi juga mengalami perubahan makna. Contohnya : مفتوح dan kata yang pertama berarti pembuka atau penakhluk sedangkan kata kedua berarti terbuka atau tertakhlukkan, yang mana kedua kata tersebut berasal dari kata فتح yang artinya membuka.

b. Kosa kata yang tidak berubah yakni kosa kata yang sejak semula sudah mempunyai bentuk dan tidak diambil dari kata lain. Contohnya : شمس، شجر، جاموس dan sejenisnya.

Secara umum media pengajaran bahasa dapat dibagi menjadi tiga jenis, yaitu media pandang (visual aids), media dengar (audio aids), dan media dengar pandang (audio visual aids). Dalam konteks pembelajaran bahasa Arab utamanya kosa kata bahasa Arab, benda-benda tiruan dan gambar yang merupakan jenis media pandang adalah media yang cukup efektif untuk digunakan (Kholisin, 2002: 3). Media-media ini dapat ditempel di dinding dan disertakan namanya dengan bahasa Arab. Sedangkan untuk jenis media dengar yang baik untuk pengajaran kosa kata bahasa Arab adalah kaset yang berisi rekaman lagu-lagu anak berbahasa Arab atau teks-teks singkat berbahasa Arab. Media pengajaran bahasa yang paling lengkap 
adalah media dengar pandang, karena dengan media ini terjadi proses saling membantu antara indera dengar dengan indera pandang. Yang termasuk jenis media ini adalah televisi, VCD, komputer, dan labolatorium bahasa yang mutakhir (Kholisin, 2002: 4).

Menurut Mustofa (2017: 61) tujuan umum pembelajaran kosa kata bahasa Arab adalah sebagai berikut :

a. Memperkenalkan kosa kata baru kepada siswa atau mahasiswa, baik melalui bahan bacaan maupun apa yang didengar.

b. Melatih siswa atau mahasiswa untuk dapat melafalkan kosa kata dengan baik dan benar karena pelafalan yang baik dan benar akan mengantarkan kepada kemahiran berbicara dan membaca secara baik dan benar pula.

c. Memahami makna kosa kata baik secara denotasi atau leksikal (berdiri sendiri) maupun ketika digunakan dalam konteks kalimat tertentu.

d. Mampu mengekspresikan dan memfungsikan kosa kata ke dalam berekspresi lisan (berbicara) maupun tulisan (mengarang) sesuai dengan konteksnya yang benar.

MTs Assalam merupakan sebuah lembaga yang berada dalam lingkungan pondok pesantren. Menurut Departemen Agama Republik Indonesia (2003: 1) "Pesantren adalah lembaga pendidikan keagamaan yang mempunyai kekhasan tersendiri dan berbeda dengan lembaga pendidikan lainnya". Yang mana pondok pesantren Assalam ini merupakan pondok yang didirikan oleh alumni dari pondok pesantren Darussalam Gontor sehingga pondok pesantren yang berada di lingkungan MTs Assalam ini setiap harinya berkomunikasi menggunakan bahasa Arab dan bahasa Inggris. Itu merupakan salah satu usaha untuk mengembangkan dan mengamalkan setiap kosa kata yang diterima. Selain itu, MTs Assalam Bangilan Tuban merupakan sebuah lembaga yang sangat mengedepankan hasil yang maksimal. Setiap pengajaran bahasa Arab Bapak/Ibu Guru menggunakan benda-benda ataupun gambargambar yang sesuai dengan tema materi yang sedang diajarkan. Dengan demikian, setiap kosa kata baru yang diajarkan siswa akan langsung terekam dalam memori pikiran siswa.

Menurut Arsyad (2010: 30) "Performance adalah bagaimana cara seseorang memakai bahasa dalam bentuk tingkah laku sebenarnya". Sebagaimana yang disampaikan Stevick (dalam Arsyad, 2010: 30) "Performance dibagi menjadi dua yaitu reflektif dan produktif. Performance yang reflektif adalah sejauhmana seorang murid memantulkan kembali apa yang dilemparkan seorang guru kepadanya. Sedangkan performance produktif seorang siswa tidak memiliki kewajiban mengikuti model bahasa yang diberikan oleh guru". Sementara itu menurut Maslow (dalam Arsyad, 2010: 31) "Performance yang produktif datang dari tempat yang lebih dalam dari diri siswa sehingga hasil yang diperoleh lebih mapan dan mantap". Setiap kosa kata yang 
diterima oleh siswa sedikit banyak harus diterapkan dalam berbicara sehari-hari. Tidak harus sama kalimatnya seperti yang diajarkan oleh bapak ibu guru akan tetapi diterapkan sesuai dengan kebutuhan berbicaranya. Dengan demikian siswa tidak akan lupa dengan kosa kata yang telah diajarkan dan hal tersebut juga membantu siswa dalam penguasaan kosa kata.

Kemampuan siswa-siswi MTs Assalam untuk berbicara bahasa Arab sudah tidak diragukan lagi karena banyaknya kosakata yang sudah diterima saat di pondok maupun pada saat pelajaran sekolah, akan tetapi mengenai kemampuan menulis belum begitu diketahui karena tidak semua siswa yang banyak memiliki kosa kata mampu menulis bahasa Arab dengan baik. Pondok pesantren Assalam Bangilan Tuban tergolong pondok pesantren yang cukup terkenal, karena banyaknya siswa-siswi yang mendaftar di pondok pesantren ini.

Kelas VIII di MTs Assalam Putri terdiri dari empat kelas yaitu A, B, C dan D. Kelas A dan $\mathrm{C}$ tergolong kelas yang siswanya memiliki kadar berpikir yang standart. Kelas B tergolong kelas yang siswanya memiliki kadar berpikir yang paling tinggi sedangkan kelas D tergolong siswanya memiliki kadar berpikir yang paling rendah. Pembagian kelas dimulai saat pertama kali masuk tes kelas I dan setiap semester tiga siswa yang mendapati nilai paling rendah akan dirolling dan dipindahkan dari kelas B ke kelas yang sesuai dengan kemampuannya. Jadi jika siswa tersebut tidak ingin tersisih dari kelasnya, setiap siswa harus mempertahankan bahkan meningkatkan kemampuannya. Penguasaan kosa kata setiap siswa tentu saja sangat berbeda karena setiap orang dilahirkan dengan kapasitas daya ingat yang berbeda. Siswa yang memiliki banyak kosa kata belum tentu bisa menulis dengan baik. Oleh sebab itu, penelitian ini bertujuan untuk mengetahui kemampuan menulis siswa kelas VIII MTs Assalam Bangilan Tuban dan juga pengaruh penguasaan kosa kata terhadap kemampuan menulis siswa Kelas VIII Mts Assalam Bangilan Tuban.

\section{METODOLOGI}

Metode penelitian yang digunakan dalam penelitian ini adalah metode penelitian kuantitatif, yaitu penelitian yang menggunakan angka-angka yang dijumlahkan sebagai data yang kemudian dianalisis. Sedangkan jenis penelitian yang digunakan yaitu penelitian percobaan (eksperimental research), yaitu penelitian yang melihat dan meneliti adanya akibat setelah subjek dikenai perlakuan pada variabel bebasnya.

Pada penelitian ini peneliti menggunakan pre-test dan post-test control grup disign (two grup design) untuk mengetahui pengaruh penguasaan kosa kata terhadap kemampuan menulis bahasa Arab.

Populasi pada penelitian ini adalah siswa kelas VIII MTs Assalam Bangilan Tuban. Sedangkan sampel pada penelitian ini adalah kelas B yang berjumlah 29 siswi dan kelas D 
yang berjumlah 26 siswi. Dan karena penelitian ini merupakan penelitian eksperimen peneliti memilih kelas D sebagai kelas yang diberikan perlakuan.

Dalam hal ini peneliti mengumpulkan data-data melalui hasil wawancara dan tes. Peneliti menggunakan tes tertulis untuk menguji dua variabel yang akan diteliti yaitu penguasaan kosa kata dan keterampilan menulis bahasa Arab. Peneliti akan menyediakan 20 butir soal untuk mengukur penguasaan kosa kata siswa MTs Assalam Bangilan Tuban yang digunakan sebagai pre-test dengan skor 5 setiap nomor. Sehingga jika seluruh butir soal benar maka siswa akan mendapatkan skor 100 yang artinya siswa sangat menguasai kosa kata yang telah disampaikan. Kemudian peneliti memberikan tugas untuk membuat sebuah karangan bahasa Arab tentang profesi sebagaimana yang ada pada silabus semester 2 kelas VIII yang digunakan sebagai posttest.

Analisis data digunakan peneliti untuk mengetahui pengaruh penguasaan kosa kata terhadap kemampuan menulis bahasa Arab dengan menggunakan pre-test dan post-test control grup design (two grup design). Rumus yang digunakan peneliti untuk menganalisis hasil pretest dan post-test adalah:

$$
t=\frac{|m x-m y|}{\sqrt{\frac{\left(\sum x^{2}+\sum y^{2}\right)}{N x+N y-2}\left(\frac{1}{N x}+\frac{1}{N y}\right)}}
$$

Keterangan $=$

$\mathrm{Mx}=$ rata-rata pre and post test

My $=$ rata-rata pre and post test

$\sum x^{2}=$ jumlah dari pre and post test

$\sum y^{2}=$ jumlah dari pre and post test

$\mathrm{N}=$ jumlah responden

Untuk mengerjakan rumus diatas maka terlebih dahulu kita mencari $\sum x^{2}$ dan $\sum y^{2}$ dengan rumus sebagai berikut :

$$
\begin{aligned}
& \sum x^{2}=\sum x^{2}-\frac{\left(\sum x\right)^{2}}{N} \\
& \sum y^{2}=\sum y^{2}-\frac{\left(\sum y\right)^{2}}{N}
\end{aligned}
$$

Setelah itu dianalisis menggunakan rumus pre-test dan post-test yang sudah tercantum diatas untuk mendapatkan hasil penelitian. Kemudian untuk menguji kevalidan data perlu dicari derajat kebebasan $(\mathrm{dk})$ dengan rumus :

$$
d k=N x+N y-2
$$


Setelah ditemukannya derajat kebebasan (dk) dan untuk mengetahui apakah Ha atau Ho yang diterima, peneliti menguji data dengan taraf signifikasi 5\%. Dengan kaidah jika $t$ hitung $\geq$ t tabel maka Ho ditolak.

\section{HASIL DAN PEMBAHASAN}

\section{Hasil Belajar Kelas Eksperimen}

Pertama, peneliti memberikan pre-test yang berupa tes penguasaan kosa kata siswa. Pada penelitian ini, peneliti membagikan lembar pertanyaan kepada setiap siswa. Berdasarkan hasil lembar pertanyaan yang didapat peneliti, didapatkan rata-rata hasil pre-test yang berupa tes penguasaan kosa kata kelas eksperimen yaitu 65, maka dapat disimpulkan bahwa siswa kelas eksperimen pada penelitian ini menguasai kosa kata dengan baik.

Tabel 1

Distribusi frekuensi pre-test kelas eksperimen

\begin{tabular}{|c|c|c|c|c|}
\hline No & $\begin{array}{c}\text { Tingkat } \\
\text { penguasaan }\end{array}$ & $\begin{array}{c}\text { Nilai } \\
\text { Interval }\end{array}$ & frekuensi & Prosentase \\
\hline 1 & Sangat Menguasai & $97-83$ & 6 & $23 \%$ \\
\hline 2 & Menguasai & $82-69$ & 4 & $15 \%$ \\
\hline 3 & Cukup Menguasai & $68-55$ & 8 & $31 \%$ \\
\hline 4 & Tidak Menguasai & $54-40$ & 8 & $31 \%$ \\
\hline \multicolumn{3}{|c|}{ Jumlah } & 26 & $100 \%$ \\
\hline
\end{tabular}

Tabel di atas menunjukkan bahwa 8 siswa (31\%) tidak menguasai kosa kata, 8 siswa (31\%) cukup menguasai kosa kata, 4 siswa (15\%) menguasai kosa kata dan 6 (23\%) siswa sangat menguasai kosa kata. Adapun rata-rata hasil pre-test yang berupa tes penguasaan kosa kata kelas eksperimen yaitu 65. Maka dapat disimpulkan bahwa siswa kelas eksperimen pada penelitian ini cukup menguasai kosa kata dengan baik.

Kedua, peneliti memberikan post-test yang berupa tes kemampuan menulis bahasa Arab yang mana pada penelitian ini peneliti memberikan perlakuan kepada salah satu kelompok responden yang disebut sebagai kelas eksperimen, yaitu peneliti memberikan beberapa kosa kata melalui vidio. Berdasarkan hasil tes yang diberikan didapatkan rata-rata hasil post-test yang berupa tes keterampilan menulis bahasa Arab yaitu 71, maka dapat disimpulkan bahwa 
siswa kelas eksperimen pada penelitian ini cukup mampu dalam pembuatan karangan/karya tulis bahasa Arab.

\section{Tabel 2}

Distribusi frekuensi post-test kelas eksperimen

\begin{tabular}{|c|c|c|c|c|}
\hline No & $\begin{array}{c}\text { Tingkat } \\
\text { Kemampuan }\end{array}$ & $\begin{array}{c}\text { Nilai } \\
\text { Interval }\end{array}$ & Frekuensi & Prosentase \\
\hline 1 & Sangat Mampu & $97-87$ & 3 & $11,5 \%$ \\
\hline 2 & Mampu & $86-75$ & 8 & $30,7 \%$ \\
\hline 3 & Cukup Mampu & $74-63$ & 9 & $34,6 \%$ \\
\hline 4 & Tidak mampu & $62-50$ & 6 & $23 \%$ \\
\hline \multicolumn{3}{|c|}{ Jumlah } & 26 & $100 \%$ \\
\hline
\end{tabular}

Tabel di atas menunjukkan bahwa 6 siswa (23\%) tidak mampu menulis bahasa Arab, 9 siswa $(34,6 \%)$ cukup mampu menulis bahasa Arab, 8 siswa $(30,7 \%)$ mampu menulis bahasa Arab dan 3 siswa (11,5\%) sangat mampu menulis bahasa Arab.

\section{Hasil Belajar Kelas Kontrol}

Pertama, peneliti memberikan pre-test yang berupa tes penguasaan kosa kata terhadap kelas kontrol. Dari hasil tersebut didapatkan rata-rata hasil pre-test yang berupa tes penguasaan kosa kata kelas kontrol yaitu 79, maka dapat disimpulkan bahwa siswa kelas kontrol pada penelitian ini menguasai dalam pembuatan karangan/karya tulis bahasa Arab.

\section{Tabel 3}

\section{Distribusi frekuensi hasil pre-test kelas kontrol}

\begin{tabular}{|c|c|c|c|c|}
\hline No & $\begin{array}{c}\text { Tingkat } \\
\text { Penguasaan }\end{array}$ & $\begin{array}{c}\text { Nilai } \\
\text { Interval }\end{array}$ & Frekuensi & Prosentase \\
\hline 1 & Sangat menguasai & $95-85$ & 11 & $38 \%$ \\
\hline 2 & Menguasai & $84-75$ & 11 & $38 \%$ \\
\hline 3 & Cukup menguasai & $74-65$ & 2 & $7 \%$ \\
\hline 4 & Tidak menguasai & $64-55$ & 5 & $17 \%$ \\
\hline \multicolumn{3}{|c|}{ Jumlah } & 29 & $100 \%$ \\
\hline
\end{tabular}


Tabel di atas menunjukkan bahwa 5 siswa (17\%) tidak menguasai kosa kata, 2 siswa (7\%) cukup menguasai kosa kata, 11 siswa (38\%) menguasai kosa kata dan 11 siswa (38\%) sangat menguasai kosa kata. Adapun rata-rata hasil pre-test yang berupa tes penguasaan kosa kata kelas kontrol yaitu 79. Maka dapat disimpulkan bahwa siswa kelas kontrol pada penelitian ini menguasai dalam membuat karangan/karya tulis bahasa Arab.

Kedua, peneliti memberikan post-test yang berupa tes kemampuan menulis bahasa Arab yang mana pada penelitian ini peneliti tidak memberikan perlakuan kepada kelas kontrol melainkan menayangkan vidio yang disediakan dan memberi lembar kertas untuk siswa menulis karangan bahasa Arab.

\section{Tabel 4}

Distribusi frekuensi hasil post-test kelas kontrol

\begin{tabular}{|c|c|c|c|c|}
\hline No & $\begin{array}{c}\text { Tingkat } \\
\text { Kemampuan }\end{array}$ & $\begin{array}{c}\text { Nilai } \\
\text { Interval }\end{array}$ & Frekuensi & Prosentase \\
\hline 1 & Sangat Mampu & $98-84$ & 8 & $28 \%$ \\
\hline 2 & Mampu & $83-70$ & 10 & $34 \%$ \\
\hline 3 & Cukup Mampu & $69-55$ & 8 & $28 \%$ \\
\hline 4 & Tidak mampu & $54-40$ & 3 & $10 \%$ \\
\hline \multicolumn{3}{|c|}{ Jumlah } & 29 & $100 \%$ \\
\hline
\end{tabular}

Tabel di atas menunjukkan bahwa 3 siswa (10\%) tidak mampu menulis bahasa Arab, 8 siswa (28\%) cukup mampu menulis bahasa Arab, 10 siswa (34\%) mampu menulis bahasa Arab dan 8 siswa (28\%) sangat mampu menulis bahasa Arab. Berdasarkan hasil tes tersebut, rata-rata hasil post-test yang berupa tes keterampilan menulis bahasa Arab yaitu 76, maka dapat disimpulkan bahwa siswa kelas kontrol pada penelitian ini mampu dalam membuat karangan/karya tulis bahasa Arab.

\section{Pengujian Hipotesis}

Hipotesis merupakan dugaan sementara terkait penelitian yang diteliti oleh peneliti. Penelitian ini bertujuan untuk mengetahui pengaruh penguasaan kosa kata terhadap kemampuan menulis bahasa Arab siswa kelas VIII MTs Assalam Bangilan Tuban Tahun Pelajaran 2019/2020”. Analisis yang digunakan adalah uji t yang akan diterangkan secara rinci sebagai berikut :

\section{Uji t penguasaan kosa kata dan kemampuan menulis bahasa Arab kelas eksperimen}


Pada tabulasi data berikut peneliti melakukan pre-test yang berupa tes penguasaan kosa kata dan post-test yang berupa keterampilan menulis bahasa Arab terhadap kelas eksperimen.

\section{Tabel 5}

Tabulasi Data Pre-test $\left(\mathrm{X}_{1}\right)$ Dan post-test $\left(\mathrm{X}_{2}\right)$ Kelas Eksperimen

\begin{tabular}{|c|c|c|c|c|}
\hline No & $\mathbf{X}_{1}$ & $\mathbf{X}_{2}$ & $x$ & $x^{2}$ \\
\hline 1 & 86 & 55 & -31 & 961 \\
\hline 2 & 75 & 85 & 10 & 100 \\
\hline 3 & 57 & 63 & 6 & 36 \\
\hline 4 & 74 & 65 & -9 & 81 \\
\hline 5 & 75 & 68 & -7 & 49 \\
\hline 6 & 40 & 58 & 18 & 324 \\
\hline 7 & 74 & 97 & 23 & 529 \\
\hline 8 & 60 & 67 & 7 & 49 \\
\hline 9 & 49 & 50 & 1 & 1 \\
\hline 10 & 65 & 78 & 13 & 169 \\
\hline 11 & 66 & 67 & 1 & 1 \\
\hline 12 & 50 & 50 & 0 & 0 \\
\hline 13 & 89 & 85 & -4 & -16 \\
\hline 14 & 40 & 50 & 10 & 100 \\
\hline 15 & 51 & 80 & 29 & 841 \\
\hline 16 & 45 & 73 & 28 & 784 \\
\hline 17 & 97 & 90 & -7 & 49 \\
\hline 18 & 84 & 81 & -3 & 9 \\
\hline 19 & 66 & 67 & 1 & 1 \\
\hline 20 & 83 & 93 & 10 & 100 \\
\hline 21 & 56 & 55 & -1 & 1 \\
\hline 22 & 90 & 85 & -5 & 25 \\
\hline 23 & 55 & 66 & 11 & 121 \\
\hline 24 & 53 & 78 & 25 & 625 \\
\hline 25 & 53 & 66 & 13 & 169 \\
\hline 26 & 59 & 83 & 24 & 576 \\
\hline \multicolumn{3}{|c|}{ Jumlah } & 163 & 5.685 \\
\hline
\end{tabular}

Berdasarkan tabel di atas, rata-rata hasil pre-test yang berupa tes penguasaan kosa kata dan post-test yang berupa keterampilan menulis bahasa Arab di kelas eksperimen adalah 6,269. 
2. Uji t penguasaan kosa kata terhadap kemampuan menulis bahasa Arab kelas kontrol

Pada tabulasi data berikut peneliti melakukan pre-test yang berupa tes penguasaan kosa kata dan post-test yang berupa keterampilan menulis bahasa Arab pada kelas kontrol.

Tabel 6

Tabulasi Data Pre-Test $\left(\mathrm{Y}_{1}\right)$ dan Post-Test $\left(\mathrm{Y}_{2}\right)$ Kelas Kontrol

\begin{tabular}{|c|c|c|c|c|}
\hline No & $\mathrm{Y}_{1}$ & $\mathrm{Y}_{2}$ & $y$ & $y^{2}$ \\
\hline 1 & 82 & 65 & -17 & 289 \\
\hline 2 & 56 & 56 & 0 & 0 \\
\hline 3 & 78 & 55 & -23 & -529 \\
\hline 4 & 88 & 79 & -9 & 81 \\
\hline 5 & 87 & 91 & 4 & 16 \\
\hline 6 & 93 & 93 & 0 & 0 \\
\hline 7 & 90 & 84 & -6 & -36 \\
\hline 8 & 74 & 79 & 5 & 25 \\
\hline 9 & 80 & 95 & 15 & 225 \\
\hline 10 & 87 & 66 & -21 & 441 \\
\hline 11 & 85 & 84 & -1 & 1 \\
\hline 12 & 79 & 40 & -39 & 1.521 \\
\hline 13 & 89 & 72 & -17 & 289 \\
\hline 14 & 85 & 85 & 0 & 0 \\
\hline 15 & 79 & 83 & 4 & 16 \\
\hline 16 & 81 & 56 & -25 & 625 \\
\hline 17 & 95 & 70 & -26 & 676 \\
\hline 18 & 55 & 70 & 15 & 225 \\
\hline 19 & 77 & 88 & 11 & 121 \\
\hline 20 & 64 & 98 & 34 & 1.156 \\
\hline 21 & 87 & 66 & -21 & 441 \\
\hline 22 & 75 & 55 & -20 & 400 \\
\hline 23 & 61 & 74 & 13 & 169 \\
\hline
\end{tabular}

Tadris, Volume 14/ No. 1/ Tahun 2020 | 30 


\begin{tabular}{|c|c|c|c|c|}
\hline 24 & 79 & 80 & 1 & 120 \\
\hline 25 & 67 & 87 & 20 & 400 \\
\hline 26 & 84 & 98 & 14 & 196 \\
\hline 27 & 62 & 92 & 30 & 900 \\
\hline 28 & 93 & 70 & -23 & -529 \\
\hline 29 & 79 & 74 & -5 & 25 \\
\hline \multicolumn{5}{|c|}{ Jumlah $1 y=-87: 29=-3$} \\
\hline
\end{tabular}

Berdasarkan tabel di atas, rata-rata hasil pre-test yang berupa tes penguasaan kosa kata dan post-test yang berupa keterampilan menulis bahasa Arab di kelas eksperimen adalah -3 .

Setelah kedua data tersaji langkah selanjutnya adalah mencari $\sum x^{2}$ dan $\sum y^{2}$ dengan rumus sebagai berikut :

$$
\begin{aligned}
& \sum x^{2}=\sum x^{2}-\frac{\left(\sum x\right)^{2}}{N}=5685-\frac{(163)^{2}}{26}=5.685-\frac{26.569}{26} \\
& =5.685-1.021,885=4.663,115 \\
& \sum y^{2}=\sum y^{2}-\frac{\left(\sum y\right)^{2}}{N}=7.264-\frac{(-87)^{2}}{29}=7.264-\frac{7.569}{29} \\
& =7.264-261=7.003
\end{aligned}
$$

Langkah selanjutnya yaitu memasukkan setiap data yang diperoleh ke dalam rumus yang digunakan untuk mengetahui pengaruh penguasaan kosa kata terhadap kemampuan menulis bahasa Arab yang mana akan disajikan sebagai berikut :

$$
\begin{gathered}
t=\frac{|m x-m y|}{\sqrt{\frac{\left(\sum x^{2}+\sum y^{2}\right)}{N x+N y-2}\left(\frac{1}{N x}+\frac{1}{N y}\right)}} \\
=\frac{|6,269-(-3)|}{\sqrt{\frac{(4.663,115+7.003)}{26+29-2}\left(\frac{1}{26}+\frac{1}{29}\right)}} \\
=\frac{9,269}{\sqrt{\frac{11.666,115}{53}\left(\frac{55}{754}\right)}}
\end{gathered}
$$




$$
\begin{gathered}
=\frac{9,269}{\sqrt{220,115(0,073)}} \\
=\frac{9,269}{\sqrt{16,068}} \\
=\frac{9,269}{4,008} \\
=2.313
\end{gathered}
$$

Untuk menemukan $\mathrm{T}$ tabel maka harus mencari dk (derajat kebebasan) terlebih dahulu dengan rumus sebagai berikut :

$$
d k=N x+N y-2=26+29-2=53
$$

$\mathrm{T}$ tabel untuk uji dua pihak dengan taraf signifikasi 5\% dengan dk 53 adalah 2,006. Kaidahnya adalah jika T hitung > T tabel maka Ho ditolak.

Tabel 7 Pengujian Hipotesis Penguasaan Kosa Kata dan

Keterampilan Menulis Bahasa Arab Siswa

Kelas Eksperimen dan Kelas Kontrol

\begin{tabular}{|c|c|c|c|c|}
\hline Data & $\begin{array}{r}\text { Rata- } \\
\text { rata }\end{array}$ & $\begin{array}{c}\mathrm{T} \\
\text { Hitung }\end{array}$ & $\begin{array}{c}\mathrm{T} \\
\text { Tabel }\end{array}$ & $\begin{array}{c}\text { Keputusan } \\
\text { statistika }\end{array}$ \\
\hline $\begin{array}{c}\text { (Pre-test) penguasaan kosa } \\
\text { kata kelas eksperimen }\end{array}$ & 65 & & & \\
\cline { 1 - 2 } $\begin{array}{c}\text { (Post-test) keterampilan } \\
\text { menulis bahasa Arab kelas } \\
\text { eksperimen }\end{array}$ & 71 & \multirow{2}{*}{2,313} & 2,006 & Ho ditolak \\
$\begin{array}{c}\text { (Pre-test) penguasaan } \\
\text { kosa kata kelas kontrol }\end{array}$ & 79 & & & \\
\hline $\begin{array}{c}\text { (post-test) ketrampilan } \\
\text { menulis bahasa Arab kelas } \\
\text { kontrol }\end{array}$ & 76 & & & \\
\hline
\end{tabular}

Berdasarkan tabel di atas maka dapat dilihat bahwa $\mathrm{T}$ hitung $(2,313)>\mathrm{T}$ tabel $(2,006)$ dengan kaidah di atas yang telah disebutkan maka Ho ditolak. Jadi ada 
pengaruh antara penguasaan kosa kata dan keterampilan menulis siswa kelas VIII MTs Assalam Bangilan Tuban Tahun Pelajaran 2019/2020.

\section{PEMBAHASAN}

\section{Penguasaan Kosa Kata Siswa kelas VIII MTs Assalam Bangilan Tuban Tahun Pelajaran 2019/2020}

Menurut Faizah (2017: 7 ) penguasaan berarti kemampuan dan kesanggupan atau perbuatan menguasai. Sedangkan kosa kata adalah satuan terkecil yang ikut menentukan kekuatan bahasa. Suja'i (2018: 64) mengatakan bahwa pengetahuan dan pemahaman arti kata dalam bahasa menjadi salah satu kunci penguasaan bahasa Arab.

Menurut Horn (dalam mustofa 2017: 60) kosa kata adalah sekumpulan kata yang berbentuk sebuah bahasa. Kosa kata merupakan salah satu dari tiga unsur bahasa yang sangat penting untuk dikuasai, kosa kata ini digunakan dalam bahasa lisan maupun tulisan, dan merupakan salah satu alat untuk mengembangkan kemampuan berbahasa seseorang.

Dengan demikian dapat disimpulkan bahwa setiap orang yang ingin menguasai bahasa Arab harus mengetahui dan memahami arti dari setiap kata bahasa Arab yang merupakan salah satu kunci penguasaan bahasa Arab.

Sebelum peneliti melakukan penelitian untuk mencari data tentang penguasaan kosa kata, peneliti terlebih dahulu melakukan wawancara dengan guru mata pelajaran yang mengampu mata pelajaran baha tersa Arab terkait penguasaan kosa kata kelas VIII B dan VIII D, yang mana hasil dari wawancaranya adalah kelas VIII B merupakan kelas yang memang tergolong kelas pandai dan kelas VIII D merupakan kelas yang rendah daya berpikirnya dari seluruh kelas VIII yang ada di MTs Assalam sehingga berdasarkan hal tersebut maka peneliti menjadikan kelas VIII B sebagai kelas kontrol dan kelas VIII D sebagai kelas eksperimen.

Untuk mengetahui data tentang penguasaan kosa kata lebih detail, peneliti menyebarkan lembar soal untuk diisi siswa yang mana hasil dari data tersebut peneliti bisa mengetahui seberapa besar penguasaan kosa kata siswa kelas VIII B (kelas kontrol) dan VIII D (kelas eksperimen). Hasil penelitian terhadap penguasaan kosa kata kelas eksperimen menunjukkan 8 siswa (31\%) tidak menguasai kosa kata, 8 siswa (31\%) cukup menguasai kosa kata, 4 siswa (15\%) menguasai kosa kata dan $6(23 \%)$ siswa sangat menguasai kosa kata. Sedangkan untuk kelas kontrol menunjukkan 5 siswa (17\%) tidak menguasai kosa kata, 2 siswa (7\%) cukup menguasai kosa kata, 11 siswa (38\%) menguasai kosa kata dan 11 siswa (38\%) sangat menguasai kosa kata. 
Berdasarkan hasil uji t diketahui rata-rata dari kelas kontrol adalah 79 dan rata-rata dari kelas eksperimen adalah 65. Sehingga dapat disimpulkan bahwa kelas kontrol dan kelas eksperimen menguasai kosa kata dengan baik.

\section{Kemampuan Menulis Siswa kelas VIII MTs Assalam Bangilan Tuban Tahun Pelajaran 2019/2020}

Tidak setiap siswa yang menguasai kosa kata bisa menulis karangan bahasa Arab dengan baik dan bagus sesuai dengan kriteria yang ada karena setiap orang memiliki wawasan yang berbeda-beda yang mana hal tersebut sangat memengaruhi karya yang akan dihasilkan oleh siswa.

Bahasa adalah suatu hal yang sangat penting dalam sebuah kehidupan manusia. Setiap daerah memiliki karakteristik yang berbeda-beda hal ini karena bahasa hidup dalam lingkungan masyarakat. Bahasa merupakan bunyi yang digunakan setiap bangsa yang memiliki aspek yang sangat luas dan merupakan perspektif yang tidak bisa dibatasi.

Menurut Nuha (2016: 25) bahasa Arab adalah kalimat-kalimat yang dipergunakan orang Arab untuk mengungkapkan tujuan-tujuan (pikiran dan perasaan) mereka. Sedangkan menurut Mustofa (2017: 57) bahasa Arab merupakan salah satu bahasa Asing yang banyak dipelajari oleh masyarakat indonesia.

Berdasarkan pendapat di batas, maka dapat disimpulkan bahwa bahasa Arab merupakan sebuah kalimat yang dipergunakan oleh orang Arab untuk berkomunikasi akan tetapi sesuai perkembangan zaman sekarang bahasa Arab tidak hanya dipelajari oleh orang Arab saja akan tetapi juga banyak dipelajari oleh masyarakat Indonesia terutama orang yang beragama islam.

Bahasa Arab memiliki 4 keterampilan, yaitu keterampilan mendengar, keterampilan berbicara, keterampilan membaca, dan keterampilan menulis. Salah satu unsur dari 4 keterampilan yang menghasilkan sebuah tulisan adalah keterampilan menulis. Menurut Djiwandono (dalam Rosyidi dan ni'mah, 2018: 158) menulis merupakan kemampuan berbahasa yang bersifat aktif-produktif yang merupakan usaha untuk mengungkapkan pikiran dan perasaan yang ada pada diri seseorang pemakai bahasa melalui bahasa.

Effendy (2012: 181) mengatakan bahwa keterampilan menulis seperti halnya keterampilan membaca adalah keterampilan komunikatif dalam tulisan dan dari sisi lain adalah keterampilan produktif seperti halnya keterampilan berbicara”.

Menurut Effendy (2012: 183) tahap-tahap latihan menulis bahasa Arab ada tujuh diantaranya : 
1) Latihan kebahasaan

Latihan kebahasaan banyak macam ragamnya, antara lain latihan rekombinasi dan transformasi. Rekombinasi adalah latihan menggabungkan kalimat-kalimat yang mulanya berdiri sendiri menjadi satu kalimat panjang. Sedangkan transformasi adalah latihan mengubah bentuk kalimat, dari kalimat positif menjadi kalimat negatif maupun kalimat berita menjadi kalimat tanya.

2) Mencontoh

Kegiatan mencontoh sepintas tampaknya tidak berguna dan membuang-buang waktu saja. Mencontoh merupakan aktivitas yang mekanis, bukan berarti siswa tidak belajar akan tetapi siswa juga belajar yang pertama tentang cara menulis dengan benar sesuai contoh, yang kedua belajar mengeja tulisan seperti yang sudah dicontohkan, dan yang ketiga belajar menggunakan bahasa arab dengan benar.

3) Reproduksi

Reproduksi adalah menulis berdasarkan apa yang telah dipelajari secara lisan. Dalam tahap ini siswa sudah mulai dilatih menulis tanpa ada model/contoh.

4) Mengarang

Mengarang banyak sekali faedahnya, ada dua macam mengarang. Pertama, mengarang yang sudah dipersiapkan yaitu sebelum mengarang siswa sudah mendapatkan materinya. Kedua, mengarang yang tidak dipersiapkan yaitu siswa tidak mendapatkan materi sebelum mengarang.

5) Mengarang terpimpin

Pada keempat tahap di atas, kalimat-kalimat yang dilatihkan masih merupakan kalimat-kalimat lepas, sedangakan pada tahap ini siswa mulai dikenalkan dengan penulisan alinea, walaupun sifatnya masih terpimpin.

6) Mengisi formulir, bagan dan sejenisnya

Ketrampilan menulis banyak diperlukan untuk hal-hal yang praktis dalam kehidupan nyata, seperti mengisis berbagai macam formulir, membuat daftar, bagan, denah dll.

7) Mengarang bebas

Pada tahap ini merupakan tahap yang melatih siswa mengutarakan isi hatinya dengan memilih kata-kata dan pola kalimat secara bebas. Namun guru hendaknya tetap memberikan bimbingan dan pengarahan.

Dengan demikian dapat disimpulkan bahwa keterampilan menulis bahasa Arab merupakan sebuah keterampilan yang produktif yang mana akan menghasilkan sebuah karangan yang berasal dari pikiran sendiri. 
Menurut Rosyidi dan Ni'mah (2018: 160) untuk dapat dipahami dan diterima dengan baik oleh pembaca, pengungkapan gagasan melalui karangan menuntut sejumlah kemampuan, antara lain :

1) Segi isi, menuntut kemampuan untuk mengidentifikasi dan merumuskan gagasan pokok yang ingin diungkapkan.

2) Kemampuan menggunakan gaya bahasa tentu sesuai dengan sifat dan tujuan penulisan karangannya. Perlu juga diperhatikan aspek ejaan, kemampuan untuk menuliskan kata-kata dan penggunaan tanda baca dengan tepat.

Beberapa contoh tes menulis adalah sebagai berikut :

1) Menceritakan gambar yaitu bentuk tes yang dilakukan dengan cara membuat karangan singkat dengan bantuan gambar.

2) Membuat singkatan yaitu dengan cara mencertakan kembali isi cerita atau naskah dengan menggunakan bahasa yang berbeda dengan bahasa yang terdapat dalam cerita atau naskah.

3) Menulis bebas yaitu membuat karangan tentang topik tertentu dengan susunan bahasa yang tidak terikat.

4) Dikte yaitu dengan cara menulis kata-kata yang dilafalkan orang lain.

5) Tes $\mathrm{C}$, yaitu pengembangan dari tes Close dengan menggunakan wacana berupa teks bacaan sebagai bahan dengan menghilangkan bagian kedua dari setiap kata yang dilakukan dengan menerapkan formula kaidah serba dua.

Pada tahap ini peneliti memberikan perlakuan kepada kelas VIII D atau bisa disebut dengan menjadikan kelas VIII D sebagai kelas eksperimen yang merupakan kelas yang sangat minim pengetahuannya, peneliti memberikan kosa kata yang nanti akan dibutuhkan siswa dalam membuat sebuah karangan bahasa Arab. Dan kelas VIII B sebagai kelompok siswa-siswa pandai berperan sebagai kelas kontrol yang mana siswa langsung membuat karangan bahasa Arab tanpa diberi kosa kata yang sekiranya dibutuhkan, sehingga kelas VIII B membuat karya tulis bahasa Arab sesuai dengan penguasaan kosa kata yang dimiliki saat ini.

Hasil penelitian kemampuan menulis bahasa Arab kelas eksperimen menunjukkan bahwa 6 siswa (23\%) tidak mampu menulis bahasa Arab, 9 siswa $(34,6 \%)$ cukup mampu menulis bahasa Arab, 8 siswa (30,7\%) mampu menulis bahasa Arab dan 3 siswa (11,5\%) sangat mampu menulis bahasa Arab. Sedangkan untuk kelas kontrol menunjukkan 3 siswa (10\%) tidak mampu menulis bahasa Arab, 8 siswa (28\%) cukup mampu menulis bahasa Arab, 10 siswa (34\%) mampu menulis bahasa Arab dan 8 siswa (28\%) sangat mampu menulis bahasa Arab. 
Berdasarkan hasil uji t diketahui rata-rata dari kelas kontrol adalah 76 dan rata-rata dari kelas eksperimen 71. Sehingga dapat disimpulkan bahwa kelas kontrol mampu dalam membuat karangan bahasa Arab dan kelas eksperimen cukup mampu dalam membuat kerangan bahasa Arab.

\section{Pengaruh Penguasaan Kosa Kata Terhadap Kemampuan Menulis Bahasa Arab Siswa kelas VIII MTs Assalam Bangilan Tuban Tahun Pelajaran 2019/2020}

Keterampilan menulis bahasa Arab merupakan sebuah keterampilan yang produktif yang mana akan menghasilkan sebuah karangan yang berasal dari pikiran sendiri. Menurut Effendy (2018: 181) secara umum pengajaran menulis bertujuan agar siswa dapat berkomunikasi secara tertulis dalam bahasa Arab, terutama untuk kebutuhan yang nyata dalam kehidupan. Kemahiran menulis mempunyai dua aspek: pertama, kemahiran membentuk huruf dan menguasai ejaan; kedua, kemahiran melahirkan fikiran dan perasaan dengan tulisan.

Inti dari kemahiran menulis dalam pengajaran bahasa terletak pada aspek yang kedua. Dalam kenyataan yang kita lihat banyak orang yang dapat menulis bahasa Arab dengan amat baik, tetapi tidak faham makna kalimat yang ditulisnya, apalagi melahirkan maksud dan pikirannya sendiri dengan bahasa Arab. Sebaliknya tidak sedikit sarjana bahasa Arab yang tulisannya seperti “eker ayam", atau bisa disebut tulisan Arabnya hampir tidak bisa dibaca dan jika terjadi demikian maka kemungkinan besar menyebabkan hasil sebuah karang tersebut tidak diminati untuk dibaca.

Adanya pernyataan ini bukan berarti menafikan pentingnya kemahiran menulis dalam aspek pertama, karena kemahiran dalam aspek pertama mendasari kemahiran dalam aspek kedua. Oleh karena itu, walaupun kemampuan alfabet Arab telah dilatihkan sejak tingkat permulaan, tetapi dalam tingkat-tingkat selanjutnya pembinaan harus tetap dilakukan. Karena untuk pembelajaran menulis pada tahap awal harus dilakukan secara terus menerus supaya pembelajarannya tidak sia-sia dan hasil karyanya menyenangkan untuk dibaca.

Berdasarkan penyajian data dan analisis data terkait penelitian dapat ditemukan hasil bahwa penguasaan kosa kata kelas eksperimen menunjukkan bahwa 8 siswa (31\%) tidak menguasai kosa kata, 8 siswa (31\%) cukup menguasai kosa kata, 4 siswa (15\%) menguasai kosa kata dan $6(23 \%)$ siswa sangat menguasai kosa kata. Adapun rata-rata pre-test dari kelas eksperimen adalah 65 .

Sedangkan penguasaan kosa kata di kelas kontrol menunjukkan bahwa 5 siswa (17\%) tidak menguasai kosa kata, 2 siswa (7\%) cukup menguasai kosa kata, 11 siswa (38\%) menguasai kosa kata dan 11 siswa (38\%) sangat menguasai kosa kata. Adapun rata-rata dari pre-testdari kelas kontrol adalah 79. 
Hasil penelitian terhadap kemampuan menulis bahasa Arab kelas eksperimen menunjukkan 6 siswa (23\%) tidak mampu menulis bahasa Arab, 9 siswa (34,6\%) cukup mampu menulis bahasa Arab, 8 siswa (30,7\%) mampu menulis bahasa Arab dan 3 siswa $(11,5 \%)$ sangat mampu menulis bahasa Arab. Berdasarkan hal tersebut dapat diambil rata-rata kemampuan menulis bahasa Arab kelas eksperimen sebesar 71 yang artinya siswa cukup mampu dalam membuat karya tulis bahasa Arab. Adapun untuk kelas kontrol menunjukkan 3 siswa (10\%) tidak mampu menulis bahasa Arab, 8 siswa (28\%) cukup mampu menulis bahasa Arab, 10 siswa (34\%) mampu menulis bahasa Arab dan 8 siswa (28\%) sangat mampu menulis bahasa Arab. Berdasarkan hal tersebut maka dapat diambil rata-rata kemampuan menulis bahasa Arab kelas kontrol sebesar 76 yang artinya kelas kontrol mampu membuat karya tulis bahasa Arab dengan baik. Dari perhitungan pre-test dan post-test hasilnya menunjukan t hitung 2,313 dan t tabel pada taraf signifikasi 5\% adalah 2,006. Karena t hitung lebih besar dari t tabel maka Ho ditolak yang artinya ada pengaruh penguasaan kosa kata terrhadap keterampilan menulis bahasa Arab.

\section{PENUTUP}

\section{Kesimpulan}

Berdasarkan pada hasil penelitian dan pembahasan, maka dapat disimpulkan beberapa hal sesuai dengan permasalahan-permasalahan dalam penelitian ini. Adapun kesimpulan tersebut adalah sebagai berikut :

Pertama, Hasil penelitian terhadap penguasaan kosa kata kelas eksperimen MTs Assalam Bangilan Tuban menunjukkan 8 siswa (31\%) yang tidak menguasai, 8 siswa (31\%) yang cukup menguasai, 4 siswa (15\%) yang menguasai dan $6(23 \%)$ siswa yang sangat menguasai. Berdasarkan hal tersebut dapat diambil rata-rata penguasaan kosa kata kelas eksperimen sebesar 65 yang artinya siswa cukup menguasai dengan baik kosa kata yang diberikan. Sedangkan untuk kelas kontrol MTs Assalam Bangilan Tuban menunjukkan 5 siswa (17\%) yang tidak menguasai, 2 siswa (7\%) yang cukup menguasai, 11 siswa (38\%) yang menguasai dan 11 siswa (38\%) yang sangat menguasai. Berdasarkan hal tersebut maka dapat diambil ratarata penguasaan kosa kata kelas kontrol sebesar 79 yang artinya kelas kontrol mengusai kosa kata dengan baik.

Kedua, Hasil penelitian terhadap kemampuan menulis bahasa Arab kelas eksperimen MTs Assalam Bangilan Tuban menunjukkan 6 siswa (23\%) yang tidak mampu, 9 siswa $(34,6 \%)$ yang cukup mampu, 8 siswa $(30,7 \%)$ yang mampu dan 3 siswa $(11,5 \%)$ yang sangat mampu. Berdasarkan hal tersebut dapat diambil rata-rata kemampuan menulis bahasa Arab kelas 
eksperimen sebesar 71 yang artinya siswa cukup mampu dalam membuat karya tulis bahasa Arab. Sedangkan untuk kelas kontrol MTs Assalam Bangilan Tuban menunjukkan 3 siswa (10\%) yang tidak mampu, 8 siswa (28\%) yang cukup mampu, 10 siswa (34\%) yang mampu dan 8 siswa (28\%) yang sangat mampu. Berdasarkan hal tersebut maka dapat diambil rata-rata kemampuan menulis bahasa Arab kelas kontrol sebesar 76 yang artinya kelas kontrol mampu membuat karya tulis bahasa Arab dengan baik.

Ketiga, Ada pengaruh penguasaan kosa kata terhadap kemampuan menulis bahasa Arab kelas VIII MTs Assalam Bangilan Tuban yang diperoleh dari uji $\mathrm{T}$ pre and post test control grup design, maka diperoleh t hitung sebesar 2,313. Hasil tersebut kemudian dibandingkan dengan $\mathrm{t}$ tabel sebesar 2,006 pada taraf signifkasi 5\%. Hasil perbandingan tersebut menunjukkan $\mathrm{t}$ hitung $(2,313)>\mathrm{t}$ tabel $(2,006)$, hal ini yang menunjukkan bahwa ada pengaruh antara penguasaan kosa kata terhadap keterampilan menulis bahasa arab kelas VIII MTs Assalam Bangilan Tuban.

\section{Saran}

Berdasarkan hasil analisis dan kesimpulan hasil penelitian, maka perlu peneliti memberi saran kepada guru mata pelajaran yang ada kaitannya dengan kemampuan menulis bahasa Arab siswa untuk lebih memperhatikan tentang penulisan terutama kaidah menulis bahasa Arab maupun mengarang dengan bahasa Arab. Sebab penguasaan kosa kata siswa saja tidaklah cukup dalam pengembangan bahasa Arab siswa.

\section{DAFTAR RUJUKAN}

Achoita, Ana. 2018. Bahasa Arab dan Metode Pengajarannya, Jurnal Tadris, Vol 12. No. 2 Desember 2018

Arsyad, Azhar. 2010. Bahasa Arab dan metode pengajarannya. Yogyakarta: Pustaka Pelajar.

Departemen Agama RI Direktorarat Jendral Kelembagaan Agama Islam. 2003. Pondok pesantren dan madrasah diniyah. Jakarta: Departemen Agama RI.

Effendy, Ahmad Fuad. 2012. Metodologi Pengajaran Bahasa Arab. Malang: Misykat.

Faizah, Nur, Siti. 2017. Korelasi Antara Penguasaan Kosakata Bahasa Arab Dengan Ketrampilan Berbicara Pada Mata Pelajaran Bahasa Arab Siswa Kelas VIII Di Smp Bustanul 'Ulum Bantarkawung. Skripsi. Tidak diterbitkan. Fakultas Tarbiyah dan Ilmu Keguruan. Institut Agama Islam Negeri : Purwokerto.

Hardjono, Sartinah. 1988. Psikologi Belajar Mengajar Bahasa Asing. Jakarta: Departemen Pendidikan dan Kebudayaan Direktorat Jenderal Pendidikan Tinggi Proyek Pengembangan Lembaga Pendidikan Tenaga Kependidikan.

Kentjono, Djoko. 1990. Dasar Dasar Linguistik Umum. Jakarta: Universitas Indonesia. 
Kholisin. 2002. Pengembangan Media Pembelajaran Al Arabiyyah lil Athfal. Makalah disajikan dalam Pelatihan Pembelajaran Bahasa Arab untuk Anak Al Arabiyyah lil Athfa:l tanggal 13 Juli 2002 (Tidak diterbitkan).

Mustofa, Syaiful, 2017. Strategi pembelajaran bahasa arab inovatif. Malang: UIN-Maliki Press.

Nuha, Ulin. 2016. Ragam metodologi \& media pembelajaran bahasa arab. Yogyakarta: UINMALIKI Press.

Rosyidi, Wahab dan Ni'mah, Mamlu'atul. 2018. Memahami konsep dasar pembelajaran bahasa arab. Malang: UIN MALIKI PRESS.

Rosyidi, Wahab, Abdul. 2017. Media pembelajaran bahasa arab. Malang: UIN-Maliki Press.

Suja'i. 2008. Inovasi pembelajaran bahasa arab. Semarang: Walisongo Press 